\title{
Artikel Penyegar \\ BERGAMOT ESSENTIAL OIL (Citrus bergamia) SEBAGAI TERAPI ALTERNATIF LANJUTAN UNTUK KOMPLIKASI KOSEHETAN YANG DISEBABKAN OLEH INTERNET GAMING DISORDER (IGD)
}

\author{
Intan Lestari ${ }^{1}$ \\ ${ }^{1}$ Universitas Brawijaya \\ Corresponding author's email: intanlestari@student.ub.ac.id
}

\begin{abstract}
ABSTRAK
Kegiatan yang disukai oleh semua orang untuk mengisi waktu luang, terkhususnya disukai oleh laki-laki, adalah bermain game online atau video-game. Meningkatnya durasi bermain game dapat menimbulkan kecanduan bermain game dan rasa resah jika tidak bermain game. Jika hal ini terus berlanjut dapat berkembang menjadi Internet Gaming Disorder (IGD) atau gaming disorder. Pada tahun 2018, International Classification of Diseases (ICD) mengeluarkan revisi ke-11 dan menyatakan bahwa "gaming disorder" resmi dinyatakan sebagai penyakit. IGD juga dapat berpotensi menyebabkan depresi, kesulitan sosial, ADHD, dan penyalahgunaan zat. Buah dari tanaman bergamot (Citrus bergamia) dapat digunakan untuk minyak esensial bergamot (BEO) dengan cara memerut dan cold pressing kulit buah. Minyak esensial bergamot banyak digunakan sebagai aromaterapi untuk meningkatkan suasana hati dan gejala-gejala gangguan stres. Bahan - bahan aromatik yang digunakan pada aromaterapi akan merangsang sistem saraf otonom sehingga saat reseptor akan menerima BEO dengan kandungan linalyl asetat dan linalool. Bau akan dihantarkan ke sistem limbik sehingga dapat memperbaiki suasana hati dan memicu pengeluaran hormon serotonin dan endorfin.
\end{abstract}

Kata kunci: gim, gangguan stres, bergamot, minyak esensial

\section{ABSTRACT}

An activity that is liked by everyone to fill the spare time, especially boys, is playing games online or video-games. The increased duration of playing games can be addictive when playing games and restlessness if he does not play games. If this thing continues it can develop into Internet Gaming Disorder (IGD) or gaming disorder. In 2018, the International Classification of Diseases (ICD) released the 11th revision and stated that "gaming disorder" was officially declared as a disease. IGD can also potentially cause depression, social difficulties, ADHD, and substance abuse. The fruit of the bergamot plant (Citrus bergamia) can be used for bergamot essential oil (BEO) by squeezing and cold pressing the fruit skin. Bergamot essential oil is widely used as aromatherapy to improve the mood and symptoms of stress disorders. The aromatic materials will stimulate the autonomic nervous system so the receptors will receive BEO containing linalyl acetate and linalool. The odor will be delivered to the limbic system so that it can improve mood and trigger the release of hormones serotonin and endorphins.

Kata kunci: game, stress disorder, bergamot, essential oil

\section{PENDAHULUAN}

Internet Gaming Disorder (IGD) di definisikan sebagai penggunaan internet yang terus-menerus dan berulang dalam bermain game, yang sering kali bermain bersama teman, yang mengarah ke penurunan atau kesulitan klinis yang signifikan. American Psychiatric Association (APA) baru-baru ini memasukkan IGD sebagai diagnosis yang potensial. APA menyimpulkan bahwa bukti sudah cukup kuat untuk memasukkan IGD kedalam Diagnostic and Statistical Manual, Fifth Edition (DSM-5) dengan tujuan untuk mendorong adanya penelitian tambahan tentang IGD. ${ }^{1}$ 
International Classification of Diseases (ICD) pada tahun 2018, mengeluarkan revisi ke11 dan menyatakan bahwa "gaming disorder" resmi dinyatakan sebagai penyakit. Dalam revisi ke-11 tersebut dinyatakan, gaming disorder sebagai pola perilaku ("digital-gaming atau "videogaming") yang ditandai dengan gangguan kontrol atas game, meningkatkan prioritas yang diberikan pada game lebih dari kegiatan lain, mengutamakan game dari minat dan kegiatan sehari-hari lainnya, dan tetap melanjutkan atau meningkatkan permainan meskipun terjadi konsekuensi negatif. Untuk mendiagnosis penyakit gaming disorder, pola perilaku pasien harus memiliki tingkat keparahan yang cukup untuk menghasilkan penurunan yang signifikan dalam fungsi pribadi, keluarga, sosial, pendidikan, pekerjaan atau bidang fungsi penting lainnya dan biasanya telah terbukti selama setidaknya 12 bulan. $^{2}$

Sebagian besar orang dengan game disorder dan yang bermain vidoe-game adalah laki-laki.3,4 Di Cina 6,3\% anak laki-laki yang bermain game terkena IGD (Internet GameDisorder) dibandingkan dengan 2,4\% perempuan $^{5}$, di Korea terdapat 3,6\% dari anak laki-laki terkena IGD dibandingkan dengan 1,9\% anak perempuan. ${ }^{6}$ Menurut (Desai et al., 2010) para pemain game, melaporkan adanya problematic gaming, yang didefinisikan sebagai laporan untuk berusaha mengurangi, memiliki hasrat yang tak tertahankan untuk bermain, dan memiliki ketegangan yang semakin besar yang hanya dapat dihilangkan dengan bermain. Anak laki-laki lebih mungkin melaporkan masalah ini $(5,8 \%)$ daripada anak perempuan $(3,0 \%)$. Jika masalah - masalah diatas tetap dibiarkan tanpa adanya penanganan, tidak memungkinkan jika IGD tersebut akan menjadi sesuatu yang lebih mengerikan. Game secara konsisten selalu dikaitkan dengan penggunaan secara kompulsif atau bermasalah. ${ }^{7}$ IGD juga dapat terhubung menjadi suatu depresi, ${ }^{2}$ kesulitan sosial, ${ }^{8}$ attention deficit hyperactivity disorder (ADHD), ${ }^{9}$ dan penyalahgunaan zat. ${ }^{10}$

\section{ISI}

\section{Bergamot (C. bergamia): Profil, Kajian Farmakologis dan Potensi anti-depresan}

Bergamot adalah nama umum untuk Citrus bergamia Risso et Poiteau, tanaman dari anggota famili Rutaceae dengan subfamili Esperidea. Citrus bergamia didefinisikan sebagai hibrida antara jeruk asam (C. Aurantium L.) dan lemon (C. Limon L.). Buah bergamot digunakan untuk minyak esensial (BEO: bergamot essential oil) yang diperoleh dengan cara memarut dan cold pressing kulit buah. BEO adalah minyak atsiri yang berwarna kehijauan atau kuning kecoklatan sesuai dengan awal atau akhir musim produksi, dengan rasa aromatik pahit dan bau khas yang menyenangkan. BEO banyak digunakan dalam industri parfum, kosmetik, makanan, dan gula karena aroma dan kesegarannya yang kuat. Senyawa kimia yang terkandung dalam BEO terdiri dari fraksi yang mudah menguap (93-96\%) dan yang tidak menguap (4-7\%). Yang pertama, terdapat monoterpene limonene (25-53\%) yang berfungsi sebagai anti-depresan, dan senyawa teroksigenasi dalam jumlah tinggi, seperti linalool (2-20\%) dan linalyl asetat (15-40\%) yang berfungsi sebagai analgesik dan anti- inflamasi, $\gamma$-terpinena, dan $\beta$ pinena. Fraksi non-volatile mengandung bergamottin, bergapten, kumarin, dan 
psoralens. ${ }^{11,12}$ BEO banyak digunakan sebagai aromaterapi untuk meningkatkan suasana hati dan gejala-gejala dari gangguan stres, seperti kecemasan, depresi dan nyeri kronis. Didukung oleh efek fisiologis dan psikologis yang disebabkan oleh penghirupan komponen volatil yang bermekanisme melalui struktur sistem limbik, seperti pembentukan hippocampal, hipotalamus, dan korteks piriform. ${ }^{13,14}$

Beberapa studi telah dilakukan untuk mengevaluasi efek anti-depresan dan ananxiolytic pada penggunaan aromaterapi BEO. Pada percobaan yang dilakukan Watanabe et al, (2015) menunjukkan bahwa BEO yang dihirup bersamaan dengan uap air memberikan efek psikologis dan fisiologis dalam jangka waktu yang relatif singkat, sehingga menegaskan bahwa bentuk perawatan ini dapat berguna untuk mengurangi stress. ${ }^{15}$ Studi yang dilakukan $\mathrm{Ni}$ et al, (2013) pasien yang menghirup uap BEO selama 30 menit di ambulans lebih tenang dan siap untuk di operasi. ${ }^{16}$ Linck et al, (2010) melakukan studi tentang efek menghirup linalool terhadap kecemasan, interaksi sosial dan perilaku agresif pada tikus menunjukkan bahwa $1 \%$ linalool bersifat anxiolytic dan meningkatkan interaksi sosial, sedangkan 3\% linalool malah menurunkan interaksi sosisal tikus yang dikaitkan dengan aksi antagonisnya pada reseptor NMDA. ${ }^{17}$ Pada uji randomized controlled trials menunjukkan hasil yang serupa, Wiebe, 1998 menguji kecemasan pra-operasi pada enam wanita dengan aromaterapi campuran (vetivert, bergamot, dan geranium) selama 10 menit menunjukkan tingkat kecemasan yang berkurang. ${ }^{18,19}$

\section{Strategi Pengaplikasian Bergamot Essential Oil pada Penderita IGD}

Percobaan Kim (2012) untuk perngobatan IGD dengan menggunakan metode CBT (Cognitive Behavioral Therapy) dan Bupropion menunjukkan bahwa penurunan signifikan terjadi pada CBT+bupropion daripada yang hanya mengkonsumsi bupropion. ${ }^{20}$ Pemberian aromaterapi BEO dapat diberikan pada saat dilaksanakan CBT atau pada saat pasien merasa dorongan kuat untuk bermain game. Dari penuturan diatas, BEO dapat dijadikan sebagai terapi alternatif untuk mencegah komplikasi IGD karena sifat anti-depresan dan anti- cemasnya. Bahan - bahan aromatik yang digunakan pada perawatan aromaterapi akan merangsang sistem saraf otonom. Reseptor akan menerima saat BEO dengan kandungan linalyl acetate dan linalool dihidu oleh hidung. Pesan aroma tersebut akan dikirim ke otak yang akan meneruskan pesan ke thalamus untuk mengidentifikasi aroma. Bau akan diinterpretasikan oleh berbagai sel neuron dan dihantarkan ke sistem limbik dan hypothalamus untuk diolah dalam bentuk impuls listrik. Sistem limbik memiliki dua bagian yaitu hipokampus (tempat pengenalan dan memori terhadap bau) serta amigdala tempat yang menjadi pusat kontrol emosi sehingga dapat memperbaiki suasana hati (mood) dan meningkatkan gelombang alfa dalam otak yang memicu pengeluaran hormon serotonin dan endorfin. Pengaturan ini akan membuat rileks dan bau yang menyenangkan akan menstimulasi thalamus untuk mengeluarkan enkefalin yang merupakan pemberi efek menenangkan. ${ }^{21}$

\section{PENUTUP}

Internet Gaming Disorder (IGD) atau gaming- 
disorder merupakan salah satu health issues terkait kesehatan mental yang dapat menyerang siapa saja, termasuk laki - laki yang biasanya lebih rentan terkena penyakit tersebut. Terapi yang dilakukan untuk IGD adalah Cognitive Behavioral Therapy dan Bupropion. IGD dapat berkomplikasi menjadi penyakit Obsessive Compulsive Disorder, depresi, ansietas, kesulitan sosial dan ADHD. Minyak essensial bergamot yang didapatkan dari kulit buah $C$. bergamia memiliki kandungan linalool dan linalyl acetate yang memiliki efek menenangkan serta dapat mengurangi gejala-gejala stres dan depresi. Kedepan, saran untuk menggunakan aromaterapi BEO kedalam regimen terapi IGD perlu segera dilakukan penelitian lebih lanjut.

\section{DAFTAR PUSTAKA}

1. American Psychiatric Association. Internet Gaming Disorder. (2013). Available from: https://www.psychiatry.org/File\%20Library/Ps ychiatrists/Practice/DSM/APA_DSM- 5Internet-Gaming-Disorder.pdf

2. WHO. (2018). Gaming disorder. Diakses tanggal 14

3. Desai RA, Krishnan-Sarin S, Cavallo D, Potenza MN. Video-gaming among high school students: Health correlates, gender differences, and problematic gaming. Pediatrics.

$$
\text { 2010;126(6):e1414-24. Available }
$$

4. WHO. (2018). Gaming disorder. Diakses tanggal 14 juli 2019 dari: https://www.who.int/features/qa/gamingdisorder/en/

5. Desai RA, Krishnan-Sarin S, Cavallo D, Potenza MN. Video-gaming among high school students: Health correlates, gender differences, and problematic gaming. Pediatrics.

2010;126(6):e1414-24. Available

6. Dong, G., Wang, Z., Wang, Y., Du, X., Potenza, MN. (2019). Gender-related functional connectivity and craving during gaming and immediate abstinence during a mandatory break: Implications for development and progression of internet gaming disorder. NeuroPshycopharmacology \& Biological Psychiatry, 88,1-10. doi: 10.1016/j.pnpbp.2018.04.009

7. WHO. (2018). Gaming disorder. Diakses tanggal 14 juli 2019 dari: https://www.who.int/features/qa/gamingdisorder/en/

8. Li, L., Yu, Q., Zhang, L,, Jin, S. (2015). The gender difference on internet addictive among adolescent: the mediation effect of the differentiation of social and psychological situation in school. Chin J Clin Psychol, 23,1044-1048.

juli 2019 dari: https://www.who.int/features/qa/gaming9. Ha, YM., Hwang, WJ. (2014). Gender differenves in internet addiction associated with psychological health indicators among adolescents using a National web-based Survey. Int J Ment Heal Addict, 12,660-669.

10. Kuss DJ, Griffiths MD, Karila L, Billieux J. Internet addiction: A systematic review of epidemiological research for the last decade. Current Pharmaceutical Design. 2014;20:4026-4052.

11. Lo SK, Wang CC, Fang W. Physical interpersonal relationships and social anxiety among online game players.

B I M F I Volume 7 No.1 / Januari 2020 - Juni 2020 
Cyberpsychology \& Behavior. 2005;8(1):1520.

12. Swing EL, Gentile DA, Anderson CA, Walsh DA. Television and video game exposure and the development of attention problems. Pediatrics. 2010;126(2):214- 221.

13. van Rooij AJ, Schoenmakers TM, Vermulst $A A$, van den Eijnden RJ, van de Mheen D. Online video game addiction: Identification of addicted adolescent gamers. Addiction. 2011;106:205-12.

14. Nabiha, B., Abdelfatteh, EO., Faten, K., Herve, C., Moncef, CM. (2010). Chemical Composition of Bergamot (Citrus Bergamua Risso) Esential Oil Obtained by Hydrodistillation. Journal of Chemistry and Chemical Engineering, 4(4), 60-61

15. Bagetta, G., Morrone, L. A., Rombolà, L., Amantea, D., Russo, R., Berliocchi, L., Corasaniti, M. T., Sakurada, S., Sakurada, T., Rotiroti, D. (2010). Neuropharmacology of the essential oil of bergamot. Fitoterapia, 81(6), 453-461. doi:10.1016/j.fitote.2010.01.013

16. Navarra M, Mannucci C, Delbo M, Calapai G. Citrus bergamia essential oil: from basic research to clinical application. Front Pharmacol [Internet]. 2015;6:36. Available from:

https://www.ncbi.nlm.nih.gov/pmc/articles/PM $\underline{\mathrm{C} 4345801 /}$

17. Watanabe, E., Kuchta, K., Kimura, M., Rauwald, HW., Kamei, T., Imanishi, J. (2015). Effects of bergamot (Citrus bergamia (Risso) Wright \& Arn.) essential oil aromatherapy on moodstates, parasympathetic nervous system activity, and salivarycortisol levels in 41 healthy
females.Forsch Komplementmed 22:43-49

18. Wiebe, E. (1998). A randomized trial of aromatherapy to reduce anxiety before abortion. Effective Clinical Practice: ECP, 3(4), 166-169.

19. Perna, S., Spadaccini, D., Botteri, L., Girometta, C., Riva, A., Allegrini, P., Petrangolini, G., Infantino, V., \& Rondanelli, M. (2019). Efficacy of bergamot: From antiinflammatory and anti-oxidative mechanisms to clinical applications as preventive agent for cardiovascular morbidity, skin diseases, and mood alterations. Food science \& nutrition, 7(2), 369-384. https://doi.org/10.1002/fsn3.903

20. Ni, CH., Hou, WH., Kao, CC., et al. (2013). The Anxiolytic Effect of Aro-matherapy on Patients Awaiting Ambulatory Surgery: A Ran-domized Controlled Trial. Evid Based Complement AlternatMed (In press).

21. Linck, V. M., da Silva, A. L., Figueiró, M., Caramão, E. B., Moreno, P. R. H., \& Elisabetsky, E. (2010). Effects of inhaled Linalool in anxiety, social interaction and aggressive behavior in mice. Phytomedicine, 17(8-9), 679-683. doi:10.1016/j.phymed.2009.10.002

22. Kim SM, Han DH, Lee YS, Renshaw PF. Combined cognitive behavioral therapy and bupropion for the treatment of problematic on-line game play in adolescents with major depressive disorder. Computers in Human Behavior. 2012;28(5):1954-1959.

23. Sharma, S. (2009). Aromaterapi. Tangerang: Karisma.

24. Mannucci, C., Navarra, M., Calapai, F., Squeri, R., Gangemi, S., \& Calapai, G. 
(2016). Clinical Pharmacology of Citrus bergamia: A Systematic Review. Phytotherapy Research, 31(1), 27-39. doi:10.1002/ptr.5734

25. Zajac, K., Ginley, MK., Chang, R., Perty, NM.
(2017). Treatments for Internet Gaming Disorder and Internet Addiction: A Systematic Review. Psychol Addict Behav, 31(8): 979-994. doi: 10.1037/adb0000315 